\title{
PENGEMBANGAN KADER SEKOLAH MENENGAH UNTUK MENURUNKAN INSIDEN THALASSEMIA DI KABUPATEN BULAK, SURABAYA
}

\section{DEVELOPMENT OF HIGH SCHOOL CADRES TO REDUCE THALASSEMIA INCIDENCE IN BULAK DISTRICT, SURABAYA: A PILOT PROJECT}

\author{
Annette d'Arqom*1, Danti Nur Indiastuti', Zamal Nasution' ${ }^{1}$, Rezi Ramawan Melbiarta ${ }^{3}$ \\ ${ }^{1}$ Division of Pharmacology, Department of Anatomy, Histology, and Pharmacology, Faculty of Medicine, \\ Universitas Airlangga, Indonesia. \\ ${ }^{2}$ Institute for Population and Social Research, Mahidol University, Thailand. \\ ${ }^{3}$ Faculty of Medicine, Universitas Airlangga Indonesia. \\ Correspondence email: annette-d-a@fk.unair.ac.id
}

\begin{abstract}
Abstrak
Thalaasemia merupakan penyakit genetik yang menyebabkan penurunan atau ketiadaan hemoglobin, yang disebabkan oleh mutasi genetik pada gen $\alpha$ dan/atau gen $\beta$ globin. Gejala utamanya adalah anemia yang bervariasi dari sedang hingga berat yang memerlukan transfusi rutin setiap bulan. Memutus mata rantai atau pencegahan thalassemia adalah satu-satunya cara dalam menangani penyakit genetik ini. Selain itu, karena perkawinan usia muda (10-24 tahun) merupakan hal yang umum di Indonesia, maka diperlukan edukasi mengenai pengenalan status dan risiko penyakit ini sejak usia dini, sebelum menikah, untuk menghentikan bayi baru lahir penderita thalassemia mayor. Mengatasi masalah di atas membutuhkan penyebaran informasi dan pelatihan yang berkelanjutan. Salah satunya adalah SAHABAT THALER, yaitu: gerakan kader mahasiswa yang paham dan siap menyebarkan ilmu ke lingkungan dan sesama. Memanfaatkan kegiatan ekstrakurikuler seperti OSIS, PMR, Rohis, dll, diharapkan pengetahuan tentang Thalasemia dapat disebarluaskan secara efektif dan efisien, terutama kepada individu usia subur. Kegiatan inisiasi ini diawali dengan pelatihan online untuk 20 kader mahasiswa dan 1 dosen pembimbing. Pelatihan diberikan oleh para ahli Farmakologi Molekuler, Patologi Klinik, Psikiatri, dan orang tua penderita Thalassemia. Pelatihan tersebut meliputi mengenal dasar-dasar Thalassemia, terapi dan skrining Thalassemia, pentingnya donor darah, aspek psikososial Thalassemia, dan berbagi pengalaman orang tua penderita Thalassemia. Para kader kemudian dibagi menjadi 4 kelompok kecil dan dipandu oleh fasilitator untuk kemudian menonton film dokumenter tentang Thalassemia dan membuat proyek mandiri yang selanjutnya disebarluaskan kepada 83 rekan sejawat. Respon lengkap yang diterima berjumlah 17 dari 20 kader, dengan 35,29\% responden pernah mendengar tentang Thalassemia dan tidak ada yang memiliki keluarga atau teman dengan Thalassamia. Namun mereka memiliki pengetahuan yang baik tentang Thalassemia sebelum pelatihan baik (rata-rata 90,16\%, kisaran 66,67-100\%) dan meningkat setelah pelatihan (rata-rata 91,67\%, kisaran 83,33-100\%). Usai pelatihan, empat produk yang terdiri dari dua video, satu Instagram, dan satu poster dibuat dan disebarluaskan kepada rekan sebaya. Pembinaan kader kelompok sebaya diperlukan untuk meningkatkan kesadaran penyakit genetik dan pentingnya skrining pranikah.
\end{abstract}

Kata Kunci: kader SMU, Thalassemia, Teman Sebaya

\begin{abstract}
Thalassemia is a genetic disease that causes decreasing or absence of hemoglobin, caused by a genetic mutation in the alpha gene or/and beta-globin gene. The main symptom is anemia which varies from moderate to severe which requires regular transfusions every month. Breaking the chain of Thalassemia or prevention is the only way in dealing with this genetic disease. Moreover, since young marriage (10-24 years) is common in Indonesia, education is needed regarding the recognition of the status and risk of this disease from an early age, before marriage, to stop the newborn with Thalassemia major. Addressing the above problems requires continuous information dissemination and training. One of these efforts is SAHABAT THALER, which is the movement of student cadres who understand and are ready to spread knowledge to the environment and peers. Taking advantage of extracurricular activities, knowledge of Thalassemia is expected to be effectively and efficiently disseminated, especially to individuals of childbearing age. This initiation activity began with online
\end{abstract}


training for 20 student cadres and 1 supervisor. Training is provided by experts in Molecular Pharmacology, Clinical Pathology, Psychiatry, and parents of Thalassemia patients. The training includes getting to know the basics of Thalassemia, therapy, and screening for Thalassemia, the importance of blood donation, psychosocial aspects of Thalassemia, and sharing experiences of parents with Thalassemia. The cadres were then divided into 4 small groups and guided by the facilitator to then watch a documentary film about Thalassemia and create an independent project which was further disseminated to 83 peers. From 20 cadres, 17 complete response was received. From the response, $35.29 \%$ ever hear about Thalassemia and no one has family or friends with Thalassemia. However, they have a good knowledge of Thalassemia before the training is good (mean $90.16 \%$, range $66.67-100 \%$ ) and increase after the training (mean 91.67\%, range 83.33-100\%). After the training, four products which are two videos, one Instagram, and one poster were created and disseminated to the peers. The development of peer group cadres is necessary to increase the awareness of the genetic disease and the importance of pre-marital screening.

Keyword: High School cadre, Peers, Thalassemia

\section{Introduction}

One of the most common monogenic disease in Southeast Asia is Thalassemia. The incidence of Thalassemia's patients or carriers with mutant on the globin gene, both $\alpha$ and $\beta$ globin is about $5-10 \%$. Large deletion in $\alpha$-globin gene and point mutation in $\beta$-globin gene cause imbalance between $\alpha / \beta$ ratio (Cao and Kan 2013). The reduction or absence of $\beta$-globin causes excess free $\alpha$-globin chains which precipitate on the cell membrane, reduce the flexibility of the red blood cells and lead to the red blood cell destruction and cause the anemia. Response of the human body to this condition is by producing erythropoietin (Epo) that increase production of new red blood cells inside and outside the bone marrow. In addition, blood transfusions and increased absorption of iron from the digestive tract contribute to iron deposition in many organs and lead to organ dysfunction leading to shorter life expectancy, lower quality of life, health, and economic burdens (Thein 2013).

Current therapy is blood transfusion and iron chelation, if needed, to remove excess iron. The only curative therapy is bone marrow transplantation or hematopoietic stem cells. Unfortunately, the high costs, limited HLA matching donors, and immunosuppression/rejection are major challenges. At present, there are more than 350-point mutations and, rarely by deletion, have been identified as the cause of this disease. Mutations can occur in the promoter region, coding sequence, and the intron region causing the containment of some intron regions and leading to a reduction or elimination of the $\beta$-globin chain production. Mutation results in the absence of a $\beta$-globin chain called $\beta$-thalassemia. Mutations resulting in a reduction in the production of $\beta$-globin chains but not completely absent are called $\beta^{+}$thalassemia (Thein 2018).

Since Indonesia is a large archipelago country with thousands of different ethnicities, molecular thalassemia screening is a challenge. About 5-10\% of the Indonesian population are $\beta$-thalassemia carriers. One small study in Central Java found IVS1-5 (G>C) to be the most common mutation in Java, followed by codon $26(\mathrm{HbE})$, and mutations in intron 1, IVS1-1 (G>A). This study involved 209 cases of $\beta$-thalassemia, and the IVS2- 654 mutation has not been found (Rujito et al. 2015). However, a review by Suthat Fucharoen found $12 \%$ of Thalassemia cases in Indonesia were IVS2-654, which is the second most common mutation after the IVS1-5 mutation (Fucharoen and Winichagoon 1992). 
In 2017, there were 8,011 patients with Thalassemia in Indonesia that projected to increase 3,000 more people each year. This disease is categorized as the fourth largest spent in national health insurance (BPJS) fund, reaching 2.15 billion in 2014 and doubled to 4.77 billion in 2016 (P2PTM 2019). This cost will certainly continue to increase if no action is taken. Prevention is the only way in dealing with this genetic disease. Early detection before marriage and genetic screening is needed. Cyprus and Italy have succeeded in reducing Thalassemia rates to the range of $0 \%$ by launched prevention programs since 1980 . The program focused on massive education and detection of mutant Thalassemia carriers for every population or early screening. Their success was also followed by ASEAN countries, such as Thailand and Malaysia (Cao and Kan 2013). With a 50\% incidence of Thalassemia, Thailand launched a national prevention program as an effort to control Thalassemia, including mandatory genetic screening for pregnant women. Unfortunately, prevention program in Indonesia is still minimum and need more massive program to increase the community awareness on this disease.

In the other hand, the rate of early marriage in Indonesia is quite common. Basic Health Survey in 2010 showed $0.2 \%$ women aged $10-14$ years, $11.7 \%$ women aged $15-19$ years, and $>56.2 \%$ of women aged 20-24 are married (RISKESDAS 2010). Therefore, education is needed regarding the recognition of the status and risk of this disease from an early age, before marriage to break the chain of Thalassemia. Focusing in East Java, Thalassemia patients in this province continue to increase, from 159 patients in 2007 to 470 patients in 2015, and 520 patients in 2017 (Adiwijaya et al. 2018).

\section{METHOD OF COMMUNITY DEVELOPMENT}

This cross-sectional study was approved by Ethical Committee, Faculty of Medicine, Universitas Airlangga No. 200/EC/KEPK/FKUA/2020, and parental informed consent was obtained before the study. Participants in this activity are twenty high school students aged 16-18 years and one teacher. The students are recruited as cadres who will spread information about Thalassemia to other students. They are trained every weekend within 4 weeks about Thalassemia, including symptoms of Thalassemia, treatment, screening, prevention, blood donation, and psychosocial aspects. The training is conducted by pharmacologists, clinical pathologists, and psychiatrists using Zoom $^{\odot}$ webinars and educational videos on YouTube. Furthermore, the cadres were divided into four small groups and accompanied by a facilitator who is also a doctor and lecturer at the Faculty of Medicine, Airlangga University to prepare the education products which are YouTube video, Instagram, and poster. The education products further spread to the peer groups before the cadres gave a webinar to their high school friends(d'Arqom, Indiastuti, and Nasution 2021).

\section{RESULT AND DISCUSSION}

\section{Result}

\section{Characteristics of respondents}

From twenty high school cadres, only 17 complete responses were received. The respondent's ages varied between 16-18 years old, the majority were female and studied at 11-12 grade. Only 35.29\% of respondents ever heard about Thalassemia and no one had 
friends or family with Thalassemia. The characteristics of the respondent were summarized in table 1 .

Table 1. Characteristics of respondent

\begin{tabular}{lll}
\hline Characteristic & N & \% \\
\hline Age & & \\
16 y. o & 7 & $41.18 \%$ \\
17 y. o & 9 & $52.94 \%$ \\
18 y. o & 1 & $5.88 \%$ \\
Sex & & \\
Male & 4 & $23.53 \%$ \\
Female & 13 & $76.47 \%$ \\
Grade & & \\
$11^{\text {th }}$ & 10 & $58.82 \%$ \\
$12^{\text {th }}$ & 7 & $41.18 \%$ \\
Heard about Thalassemia & & \\
Yes & 6 & $35.29 \%$ \\
No & 11 & $64.71 \%$ \\
Knowing Thalassemic Patients & & \\
Yes & 0 & $0 \%$ \\
No & 17 & $100 \%$ \\
\hline
\end{tabular}

\section{Knowledge on Thalassemia}

Interestingly, their knowledge on Thalassemia, especially the definition, spreading of the genetic disease, the symptoms, the importance of pre-marital screening, blood donation, and psychosocial aspect of the patients and the family, before the training was very good (90.17\%, range $66.67-100 \%)$ and increase after the training $(91.67 \%$, range $83.33-100 \%)$ as presented in figure 1. Their knowledge before training was associated with age, was the younger age more likely to have a higher score $(p<.011)$. Moreover, there were no significantly associated sociodemographic factors with their knowledge after the online training (Table 2).

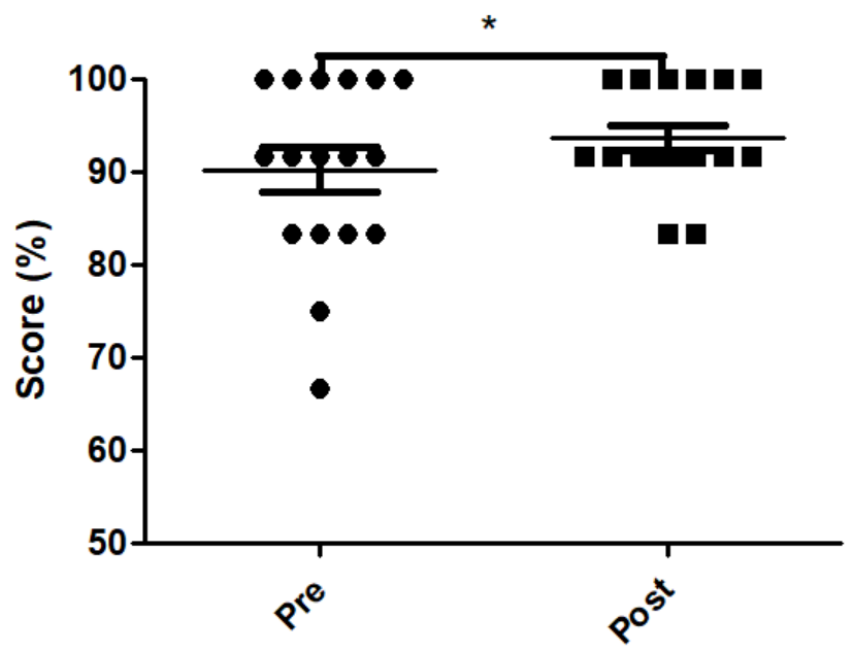

Figure 1. Knowledge of cadres before and after the online training, p-value $<0.05$. 
Table 2. Sociodemographic factor associated with knowledge on Thalassemia.

\begin{tabular}{|l|c|c|c|c|c|c|c|c|}
\hline & \multicolumn{2}{|c|}{ Age } & \multicolumn{2}{c|}{ Sex } & \multicolumn{2}{c|}{ Grade } & \multicolumn{2}{c|}{ Heard } \\
\hline & $\mathbf{x}^{\mathbf{2}}$ & $\boldsymbol{p}$ & $\mathbf{x}^{\mathbf{2}}$ & $\boldsymbol{p}$ & $\mathbf{x}^{\mathbf{2}}$ & $\boldsymbol{p}$ & $\mathbf{x}^{\mathbf{2}}$ & $\boldsymbol{p}$ \\
\hline Pretest & 19.82 & .011 & 6.13 & .187 & 7.16 & .128 & 1.53 & .822 \\
\hline Posttest & 8.94 & .063 & .944 & .624 & 1.63 & .442 & 1.43 & .489 \\
\hline
\end{tabular}

Note: Boldface $p$-values indicate a significant association between the sociodemographic factor and the knowledge.

Moreover, the cadres created four education products which were two videos in the SAHABAT THALER YouTube channel, an Instagram post at @ sahabat_thaler, and a poster. The video's content was focused on the definition, treatment, and importance of pre-marital screening of this monogenic disease, while Instagram focused to increase the familiarity with Thalassemia. Furthermore, the poster was focused on screening and early detection (Figure 2 A-C).

A)

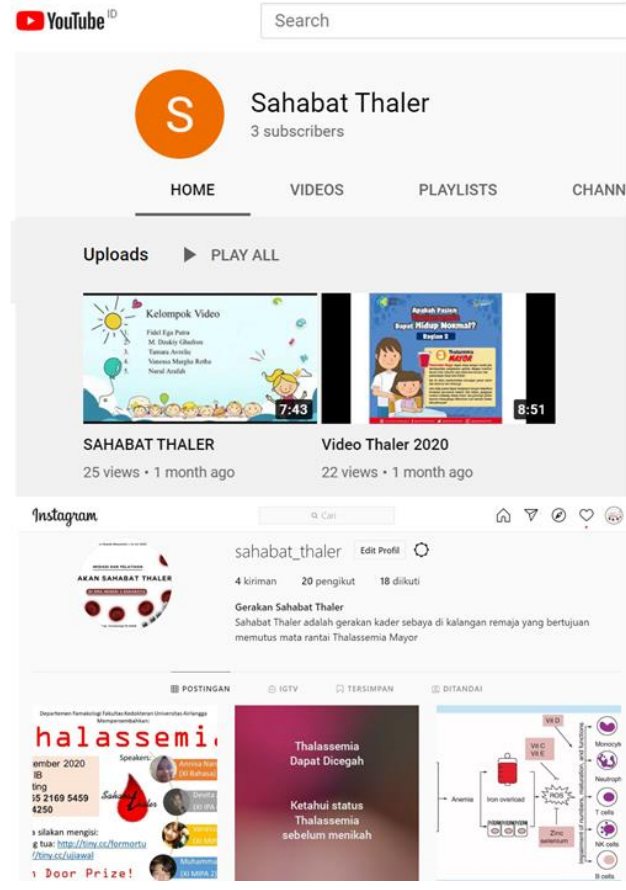

B)
C)

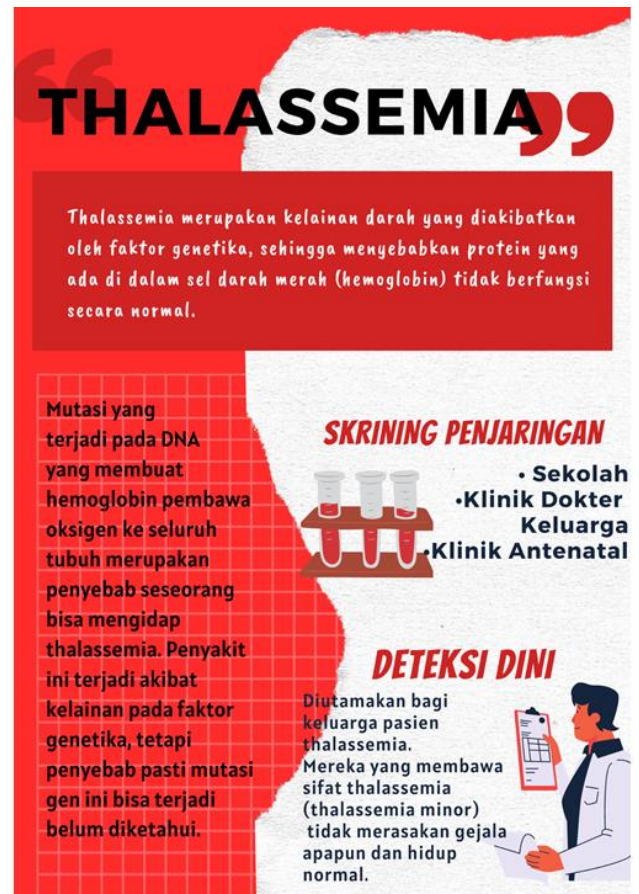

Figure 2. Education products on Thalassemia created by high school cadres. A) Sahabat Thaler YouTube channel, B) Instagram sahabat_thaler, C) Poster.

After dissemination of education products to their peer groups, cadres performed the webinars to 83 participants with similar topics as the training. The results showed increases in participant's knowledge of Thalassemia, even though the participants already have a high score before the training. Unfortunately, their knowledge was not in line with their understanding. This might be caused by the possibility of participants accessing the 
information via the internet during the pretest. Complete results could be accessed in our study about online education of Thalassemia during the COVID-19 pandemic (d'Arqom, Indiastuti, and Nasution 2021).

To improve this training, evaluation was performed after the webinar's activity. Choosing the active students that could actively engage as the cadres and join the activities was important for the sustainability of the program. Moreover, arranging the time of the activity thus will not interfere with the intra-curricula activity was essential, since student's tasks were highly increased during the online activity. Preparing a good internet connection also supported effective online training.

\section{Discussion}

Despite Thalassemia is an old genetic disease, its incidence keeps growing and still become a burden in Indonesia, including East Java. Without a prevention program, this disease will become a huge burden due to a long-life treatment needed which are blood transfusion and iron chelation agent. Successful prevention program, including genetic screening and massive education, has been shown by Cyprus and Italy. Their successful program was further followed by other countries including Malaysia and Thailand, even though the last two countries still face several challenges to reduce the incidence of this monogenic disease.

In Indonesia itself, improvement of the prevention program is needed. Due to the large population, genetic screening and massive education are hard to reach the prone population. Another challenge is the young marriage behavior in the Indonesian population. Therefore, this community development program focuses on Thalassemia education in late adolescents, especially high school students. This pilot project showed the development of the high school cadres that can be focus to train and spreading the knowledge on Thalassemia to their peers. Four education or promotion media also create by the cadres which further disseminate to their high school friends.

Increasing numbers of cadres and performed more education to another school about Thalassemia or other genetic diseases via online platforms might become a solution during this pandemic. Moreover, building a young friendly website also important to reach a wider population, as shown in COVID-19 and mental health that reach 8 million visitors within less than one year (d'Arqom et al. 2020), which can be implemented for Thalassemia.

\section{CONCLUSION}

During the COVID-19 pandemic, the education can be performed using an online platform combine with the development of peer-groups cadres shown to be effective to increase the knowledge of the students. However, we cannot control the participants during the activity and ensuring their understanding. Moreover, the evaluations conducted using the pre-test and post-test are very likely to be biased, because participants can access the internet and other information before filling out the questionnaire. In addition, the peer approach facilitates the transfer of information to the target activities and reduces language barriers and feelings of embarrassment. 


\section{Acknowledgement}

This study was funded by RKAT Faculty of Medicine Universitas Airlangga No. 281/UN3.1.1/PM/2020

\section{References}

Adiwijaya, Saputra, Airlangga Airlangga, et al. 2018. "Empowerment Pattern for Thalasemi Patients in Dr. Soetomo Hospital Surabaya (Study of the Association of Parents with Thalassemia Indonesia, Surabaya)." Budapest International Research and Critics Institute (BIRCI-Journal) : Humanities and Social Sciences 1 (12/26): 289-298. https://dx.doi.org/10.33258/birci.v1i4.121.

Cao, Antonio, and Yuet Wai Kan. 2013. "The Prevention of Thalassemia." Cold Spring Harbor perspectives in medicine 3, no. 2: a011775-a011775. https://dx.doi.org/10.1101/cshperspect.a011775.

d'Arqom, Annette, Danti Nur Indiastuti, et al. 2021. "Online Peer-Group Activism for Thalassemia Health Education During the Covid-19 Pandemic: A Case Study from East Java, Indonesia." Journal of Health Research ahead-of-print, no. ahead-of-print. Accessed 2021/05/22. https://dx.doi.org/10.1108/JHR-09-2020-0442.

d'Arqom, Annette, Brihastami Sawitri, et al. 2020. "Development of Online Mental Health Supporting Group to Reduce Mental Burden During Covid-19 Pandemic." Journal of $\begin{array}{lllll}\text { Public Service } & 4, & \text { no. } & 251-8 .\end{array}$ https://dx.doi.org/http://dx.doi.org/10.20473/jlm.v4i2.2020.251-258.

Fucharoen, Suthat, and Pranee Winichagoon. 1992. "Thalassemia in Southeast Asia: Problems and Strategy for Prevention and Control." Southeast Asian J Trop Med Public Health 23, no. 4 (Dec): 647-55.

P2PTM. 2019. "Hari Talasemia Sedunia 2019 : Putuskan Mata Rantai Talasemia Mayor." Accessed 22 September, 2020. Retrieved from: http://p2ptm.kemkes.go.id/kegiatanp2ptm/pusat-/hari-talasemia-sedunia-2019-putuskan-mata-rantai-talasemia-mayor.

RISKESDAS. 2010. "Riset Kesehatan Dasar." Accessed 22 September, 2020. Retrieved from: http://kesga.kemkes.go.id/images/pedoman/Riskesdas\%202010\%20Nasional.pdf.

Rujito, Lantip, Muhammad Basalamah, et al. 2015. "Molecular Scanning of B-Thalassemia in the Southern Region of Central Java, Indonesia; a Step Towards a Local Prevention Program." Hemoglobin 39, no. 330-3. https://dx.doi.org/10.3109/03630269.2015.1065420.

Thein, Swee Lay. 2013. "The Molecular Basis of B-Thalassemia." Cold Spring Harbor perspectives in medicine 3, no. 5: a011700-a011700. https://dx.doi.org/10.1101/cshperspect.a011700.

Thein, Swee Lay. 2018. "Molecular Basis of B Thalassemia and Potential Therapeutic Targets." Blood Cells Mol Dis 70, no. May: 54-65. https://dx.doi.org/https://dx.doi.org/10.1016/j.bcmd.2017.06.001. 